\title{
Dynamics of Internationalization and Outward Investment: Chinese Corporations' Strategies
}

\author{
Eunsuk Hong and Laixiang Sun
}

RP-07-009

December 2007

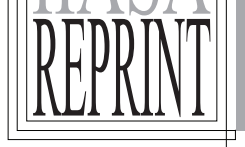





\title{
Dynamics of Internationalization and Outward Investment: Chinese Corporations' Strategies
}

\author{
Eunsuk Hong \\ Department of Financial and Management Studies, SOAS, University of London, \\ UK \\ Laixiang Sun \\ International Institute for Applied Systems Analysis, Laxenburg, Austria
}

RP-07-009

December 2007

Reprinted from The China Quarterly, 187: pp. 610-634 (2006).

International Institute for Applied Systems Analysis • Schlossplatz 1 - A-2361 Laxenburg • Austria Tel: (+43 2236) 807 • Fax: (+43 2236) 71313 • E-mail: publications@iiasa.ac.at •Web: www.iiasa.ac.at 
IIASA Reprints make research conducted at the International Institute for Applied Systems Analysis more accessible to a wider audience. They reprint independently reviewed articles that have been previously published in journals. Views or opinions expressed herein do not necessarily represent those of the Institute, its National Member Organizations, or other organizations supporting the work.

Reprinted with permission from The China Quarterly, 187: pp. 610-634 (2006).

Copyright () 2006.

All rights reserved. No part of this publication may be reproduced or transmitted in any form or by any means, electronic or mechanical, including photocopy, recording, or any information storage or retrieval system, without permission in writing from the copyright holder. 


\title{
Dynamics of Internationalization and Outward Investment: Chinese Corporations' Strategies*
}

\author{
Eunsuk Hong and Laixiang Sun
}

ABSTRACT China's success in attracting the inflow of foreign direct investment (FDI) has been well documented. Less known is the initial success of China's "going out" strategy, which encourages domestic enterprises to participate in international capital market and to directly invest overseas. This article assesses the aggregate dynamics of China's outward FDI in a comparative prism. It traces the strategic shift of Chinese overseas investment in both arenas of government policy and corporate entrepreneurship. An emphasis is on the particularistic policies of the government and active responses of enterprises to the challenges and opportunities offered by globalization and the deepening reform. The article also discusses the strategic implications of emerging Chinese multinationals for their Western counterpart.

China's success in attracting the inflow of foreign direct investment (FDI) is well known. By the end of 2003, the total stock of FDI inflow amounted to US\$501 billion. In 2003, as a result of the decline in global merger and acquisition (M\&A) volume, China surpassed the United States to become the world's biggest recipient of FDI. ${ }^{1}$ Recent surveys of international investors have consistently shown China as one of the top destinations for FDI. ${ }^{2}$

Less known, however, is the fact that in parallel with success in attracting inward FDI, China has achieved initial success in implementing its "going out" (zouchuqu 走出去) strategy, which encourages domestic enterprises to play a part in international capital markets and to invest overseas. ${ }^{3}$ At the macroeconomic level, the strategy of "going out" is largely consistent with China's persistent trade surplus and positive saving-investment gap. ${ }^{4}$ At the firm level, China's enterprises have strong interests to implement internationalization strategies by way of overseas investment. As a result, some

* We are grateful to Christopher Howe for his invaluable comments and suggestions. We have benefited from the comments of the seminar participants at SOAS of University of London and Royal Institute of International Affairs in London. Eunsuk Hong acknowledges gratefully the financial support of the ILJU Academic and Cultural Research Foundation of Korea.

1. UNCTAD (United Nations Conference on Trade and Development), World Investment Report 2004 (New York and Geneva: United Nations, 2004), pp. 367-371.

2. Atkearney, FDI Confidence Index. Vol. 6 (September 2003). Available at http:// www.atkearney.com/shared_res/pdf/FDICI_Sept_2003_S.pdf; MIGA (Multilateral Investment Guarantee Agency of the World Bank Group), Benchmarking FDI Competitiveness in Asia (Washington, DC: World Bank Group/MIGA, 2003).

3. Shi Guangsheng, "Speech in the 16th National Congress of the Communist Party of China," Renmn ribao (People's Daily), 13 November 2002.

4. John Wong and Sara Chan, "China's outward direct investment: expanding worldwide," China: An International Journal, Vol. 1, No. 2 (2003), pp. 273-301.

(C) The China Quarterly, 2006 doi: 10.1017/S0305741006000403 
Chinese brands have achieved considerable success in the global market. These include Haier (home appliances), Konka (colour televisions), TCL (multi-electronics), Jianlibao (beverages), Tsingtao (beer), Galanz (microwaves) and others. ${ }^{5}$ Haier Group exports to more than 150 countries and has 22 production facilities and 18 design centres outside China. In 2002, Haier occupied almost half of the American mini-refrigerator market, with most of its production manufactured in Haier's factory in South Carolina. Galanz, which produces over 40 per cent of microwave ovens in the world, captured 40 per cent of the European market in 2002 under its own brand name. ${ }^{6}$

According to the Ministry of Commerce, the successor of the former Ministry of Foreign Trade and Economic Co-operation (MOFTEC), by the end of May 2004 China had set up 7,720 "nontrade" enterprises overseas with a cumulative investment of US\$12.2 billion mainly in manufacturing and natural resources sectors. According to the data of UNCTAD, which include trade-related capital movement and are based on balance of payment accounting, by 2003 China had emerged as one of the largest sources of outward direct investment among 123 developing economies, being ranked number five after Hong Kong, Singapore, Taiwan and Brazil. ${ }^{7}$

Generally speaking, China's outward FDI is similar in character to that of other third-world multinationals. That is to say it is determined by advantages in cost and flexibility rather than technological advantage. ${ }^{8}$ However, the internationalization mode of Chinese multinationals is unlike that of third-world peers. Typically, Chinese multinationals establish joint ventures with Western multinationals within China before making overseas investments and they often use equity joint-venture and M\&A in order to acquire advanced production, technology and managerial skills overseas. ${ }^{9}$ Notwithstanding its increasing importance, there has been inadequate research on China's outward FDI in general and on the internationalization strategies of Chinese companies in particular. In sharp contrast to the huge body of literature on FDI inflow to China,

5. Fiona Gilmore and Serge Dumont, Brand Warriors: China Creating Sustainable Brand Capital (London: Profile Books Ltd, 2003).

6. Zeng Ming and Petter J. Williamson, "The hidden dragons," Harvard Business Review, Vol. 81, No. 10 (2003), pp. 92-99; Deng Dehai and Jian Zhou, Made in Galanz: A Miracle Story (Nanchang: Jiangxi remin chubanshe, 2004); Donald Sull, Made in China: What Western Managers Can Learn from China's Trailblazing Entrepreneur (Cambridge MA: Harvard Business School Press, 2005).

7. UNCTAD, World Investment Report 2004, pp. 382-86.

8. Sanjaya Lall, in collaboration with Edward Chen, Jorge Katz, Bernardo Kosacoff and Annibal Villela, The New Multinationals: The Spread of Third World Enterprises (Chichester: John Wiley and Sons, 1983).

9. Zhang Hai-Yan and Daniel van den Bulcke, "International management strategies of Chinese multinational firms," in John Child and Yuan Lu (eds.), Management Issues in China: Volume II, International Enterprises (London: Routledge, 1996); Wong and Chan, "China's outward direct investment," pp. 273-301. 
few academic publications examine China's overseas direct investment. The latter literature is now emerging and, typically, provides introductory analyses of Chinese government policy and the regulatory framework regarding outward investment, and/or a preliminary assessment of development trends, regional patterns and investment motivations. ${ }^{10}$ There has been a shortage of research to put this Chinese phenomenon into the context of the rise of East Asian capital outflows and to examine the shifts in economic motives and strategic orientations of Chinese multinationals at the firm level.

This article intends to add to the literature by focusing on the dynamics of investment strategies at the levels of both the government and enterprises. First, it analyses the aggregate data in order to assess the progress and performance of China's outward FDI. It then compares the dynamics of China's outward FDI with the cases of South Korea and Japan in order to identify the extent to which Chinese experience has followed or diverged from their development paths. It then studies company-level data and cases based on company reports, profiles and websites. The company-level data and cases provide illustrative examples of Chinese companies' investment activities and allow an examination of the evolving dynamics of government policies towards them, and the initiations and innovations at the company level. The article highlights the rapid rise of

10. Some researches focused on a certain region or country, such as South-East Asia (Friedrich Wu and Yoeo Han Sia, "China's rising investment in Southeast Asia: trends and outlook," Journal of Asian Business, Vol. 18, No. 2 (2002), pp. 41-61); Hong Kong (Chan Hing Lin, "Chinese investment in Hong Kong: issues and problems," Asian Survey, Vol. 35, No. 10 (1995), pp. 941-954; Sung Yun-Wing, "Chinese outward investment in Hong Kong: trends, prospects and policy implication," OECD Development Centre Technical Papers 113 (OECD, 1996); Tseng Choosin, "Foreign direct investment from the People's Republic of China," in Henri-Claude de Bettignies (ed.), Business Transformation in China (London: International Thomson Business Press, 1996), pp. 85-114); Australia (David Wall, "Outflow of capital from China," OECD Development Center Technical Papers 123 (OECD, 1997)); or Russia (Wu Hsiu-Ling and Chen Chien-Hsun, "An assessment of outward foreign direct investment from China's transitional economy," Europe-Asia Studies, Vol. 53, No. 8 (2001), pp. 1235-54). On the basis of data sources, this literature can be grouped into MOFTEC data-based research (Wu and Sia, "China's rising investment," pp. 41-61; Wu and Chen, "An assessment," pp. 1235-54; Tseng Choosin, "Foreign direct investment"); BoP accounting data-based research (Kevin G. Cai, "Outward foreign direct investment: a novel dimension of China's integration into the regional and global economy," The China Quarterly, No. 160 (1999), pp. 856880; Mizra Hafiz, "The globalization of business and East Asian developing-country multinationals," in Neil Hood and Stephan Young (eds.), The Globalization of Multinational Enterprise Activity and Economic Development (London: Macmillan, 2000), pp. 202-224; Terry Sicular, "Capital flight and foreign investment: two tales from China and Russia," World Economy, Vol. 12, No. 5 (1998), pp. 589-602); case studies (Friedrich Wu, "Stepping out the door," China Business Review, Vol. 20 , No. 6 (1993), pp. 14-19; Michael Mcdermott and Huang Chun Hua, "Industrial state-owned multinationals from China: the embryonic years, 1985-92," Asia Pacific Business Review, Vol. 3, No. 1 (1996), pp. 1-15); and questionnaire surveys (Zhang and Bulcke, "International management strategies"; Mark Yaolin Wang, "The motivations behind China's government-initiated industrial investment overseas, " Pacific Affairs, Vol. 75, No. 2 (2002), pp. 187-206). 
enterprise-led overseas investment, despite the constraints imposed by China's political system and economic transition. It examines investment mechanisms and financing channels with a focus on the rising importance of transnational M\&A and of using international listing as a key technique to raise capital to finance M\&As. It also explores the strategic implications of emerging Chinese multinationals for their Western counterparts.

\section{Aggregate Dynamics of China's Outward FDI}

China does not yet have systematic and comprehensive statistics of outward FDI comparable in quality and coverage to those of the Japan Statistics Bureau and the Export-Import Bank of Korea. ${ }^{11}$ To assess the aggregate dynamics of China's outward FDI, the best available figures are the Balance of Payments based data reported in UNCTAD's World Investment Report. These data are relatively consistent over time and across countries in terms of methodology. The resultant capital flow data have a much broader coverage than those of MOFTEC. The MOFTEC data, although providing a detailed record of "non-trade" capital movement, exclude several key sources of financial capital movement, and report only rarely the trade-related capital flows to the media.

The usual complaint against China's balance of payments based data is the unusually large figures for "errors and omissions." This figure reached a peak-outflow of US\$22 billion in $1997,{ }^{12}$ a figure equivalent to 2.4 per cent of China's GDP in that year. We argue that the "errors and omissions" figures are not simply "hidden" capital outflows. They can be explained largely by the mis-invoicing (transfer pricing) of intra-firm transactions across the border between the mainland and Hong Kong. ${ }^{13}$ It is, therefore, reasonable to assume that the extent of underestimation in the balance of payments data for China's outward FDI is limited and we can justify a comparative assessment based on UNCTAD's data.

Following UNCTAD's World Investment Report, it is clear that China is rapidly emerging as an important player in the world capital

11. http://www.mof.go.jp (Ministry of Finance Japan); http://www.koreaexim.go.kr (Export-Import Bank of Korea).

12. IMF (International Monetary Fund), International Financial Statistics (Washington, DC: The IMF Statistics Department, 1998).

13. From 1992 to 1998 , the errors caused by mis-invoicing of the mainland's trade transactions were almost exactly offset by opposite errors in the mis-invoicing of Hong Kong's trade transaction. A moderate portion of the figure could be attributed to repatriated profits from foreign enterprises which are not recorded in the balance of payments statistics as outflow (Frank R. Gunter, "Capital flight from China: 1984 2001," China Economic Review, Vol. 15, No. 1 (2004), pp. 63-85). Another moderate proportion would correspond to real statistical discrepancies. The remaining part might be assigned as hidden capital flight, but a large proportion of such capital flight often flows back to China and becomes "new FDI" after "round tripping" (Tseng Wanda and Harm Zebregs, "Foreign direct investment in China: some lessons for other countries," IMF Policy Discussion Paper (February 2002). 
market. China's share of the total overseas FDI stock of developing countries increased from 0.2 per cent in 1985 to 4.31 per cent in 2003. The accumulated book value of China's outward FDI reached about US $\$ 37$ billion by the end of 2003, which put China into the top five among 123 developing economies (Table 1).

A comparison of aggregate outward FDI between China, Korea and Japan is presented in Figure 1. This figure suggests that China and Korea experienced similar trends during the period of 1988-2002 and, to a great extent, the Chinese and Korean trends resemble those of Japan 20 years ago, although the flow from China showed a higher variation and the trend was less steep. The time lag between the Chinese and Japanese trends may not be a surprise, but the similarity between the Chinese and Korean trend is worth further discussion. The disruption of the Asian financial crisis in 1997 and 1998 moderated considerably the growth trend of capital outflow from South Korea. Without this factor, South Korea would be in a more advanced stage than China in terms of direct capital exporting, thus the difference between the two would be more in line with the investment-development path theory of Dunning. ${ }^{14}$ Nevertheless, in the event, the Asian crisis has flattened the growth trend of South Korean outward FDI since 1997, which makes the two cases appear to be approximately parallel.

Figure 2 illustrates the impact of the Asian financial crisis on South Korean domestic fixed capital formation. Before 1997, China and Korea shared a surprising similarity in both magnitude and growth trend of domestic fixed capital formation. The crisis cut the scale of Korean domestic fixed capital formation by one-third in 1997 and flattened the subsequent trend. In contrast, the strong investment growth trend in China was maintained. Thus while the ratio of China's outward FDI to its domestic fixed capital formation did not increase during the phase of the strong growth in domestic fixed capital formation, and in fact fell behind it, in Korea, the ratio of outflow to domestic investment increased because of the collapse of domestic fixed capital formation (Figure 3).

Although Figure 1 alone does not suggest a difference in development stages of capital exports between China and South Korea, the combination of Figures 1 to 3 does. Also, it is worth noting that while the Asian crisis cut the level of Korean domestic fixed capital formation by a large proportion, it only flattened the trend of Korean outward FDI flow. This indicates that Korean FDI is associated with parts of the Korean economy less vulnerable to the domestic business/investment cycle and to shocks from the international financial market. In contrast, Figure 3 suggests that China's direct investment overseas is closely associated with the domestic business/investment cycle.

14. John H. Dunning, Explaining International Production (London: Unwin Hyman, 1988). 


\section{Table 1: The Ranking of Outward FDI Stock in Developing} Economies, 1985 and 2003

\begin{tabular}{|c|c|c|c|c|c|c|c|}
\hline \multicolumn{4}{|c|}{1985} & \multicolumn{4}{|c|}{2003} \\
\hline Rank & $\begin{array}{l}\text { Region/ } \\
\text { country }^{a}\end{array}$ & $\begin{array}{l}\text { Stock (US\$ } \\
\text { million) }\end{array}$ & $\begin{array}{c}\text { Share } \\
(\%)\end{array}$ & Rank & $\begin{array}{l}\text { Region/ } \\
\text { country }^{b}\end{array}$ & $\begin{array}{l}\text { Stock (US } \\
\% \text { million) }\end{array}$ & $\begin{array}{l}\text { Share } \\
(\%)\end{array}$ \\
\hline 1 & Brazil & 38,545 & $(52.12)$ & 1 & $\begin{array}{l}\text { Hong } \\
\text { Kong }\end{array}$ & 336,098 & $(39.14)$ \\
\hline 2 & South Africa & 8,963 & (12.12) & 2 & Singapore & 90,901 & (10.59) \\
\hline 3 & Argentina & 5,944 & $(8.04)$ & 3 & Taiwan & 65,232 & $(7.60)$ \\
\hline 4 & Singapore & 4,387 & (5.93) & 4 & Brazil & 54,646 & $(6.36)$ \\
\hline 5 & Hong Kong & 2,344 & $(3.17)$ & 5 & China & 37,006 & (4.31) \\
\hline 6 & Panama & 2,204 & (2.98) & 6 & $\begin{array}{l}\text { South } \\
\text { Korea }\end{array}$ & 34,531 & $(4.02)$ \\
\hline 7 & Bermuda & 1,691 & (2.29) & 7 & Malaysia & 29,686 & (3.46) \\
\hline 8 & Kuwait & 1,408 & (1.90) & 8 & $\begin{array}{l}\text { Virgin } \\
\text { Islands }\end{array}$ & 26,810 & (3.12) \\
\hline 9 & Malaysia & 1,374 & (1.86) & 9 & $\begin{array}{l}\text { South } \\
\text { Africa }\end{array}$ & 24,195 & $(2.82)$ \\
\hline 10 & Bahrain & 599 & $(0.81)$ & 10 & $\begin{array}{c}\text { Cayman } \\
\text { Islands }\end{array}$ & 21,884 & $(2.55)$ \\
\hline 26 & China & 131 & $(0.18)$ & & & & \\
\hline \multicolumn{2}{|c|}{$\begin{array}{l}\text { Other developing } \\
\text { economies }\end{array}$} & 6,493 & $(8.78)$ & \multicolumn{2}{|c|}{$\begin{array}{l}\text { Other developing } \\
\text { economies }\end{array}$} & 116,389 & (13.55) \\
\hline \multicolumn{2}{|c|}{$\begin{array}{l}\text { Total developing } \\
\text { economies }\end{array}$} & 73,952 & $(100)$ & \multicolumn{2}{|c|}{$\begin{array}{l}\text { Total developing } \\
\text { economies }\end{array}$} & 858,681 & $(100)$ \\
\hline
\end{tabular}

Notes:

${ }^{\text {a }}$ Total 65 countries involved in outward FDI.

${ }^{\mathrm{b}}$ Total 123 counties involved in outward FDI.

Source:

UNCTAD (2004), World Investment Report 2004, Annex table B.4., pp. 382-86.

\section{Shift in the Strategies of Overseas Direct Investment ${ }^{15}$}

Evolution of general policies and the role of particularistic policies. Since the late 1970s, China's outward FDI has changed in every important respect. In terms of objectives, it has moved from being politically to being commercially motivated. In terms of key actors, central government has given way to local government and, now, to enterprise-led activity. Finally, in terms of strategic orientations, natural resource seeking investment has broadened to a much wider

15. MOFTEC's statistics on overseas investment are classified into two main types: trade and non-trade. "Trade" refers to investment in service sectors including banking, commercial office, catering, travel agency etc., whereas "non-trade" refers to investment in industrial manufacturing and resource extraction. As mentioned before, because of the lack of statistical track data on the "trade" category, this section will focus on the overseas investment in the "non-trade" category only. 
Figure 1: Total Outward FDI Flows from China, South Korea and Japan

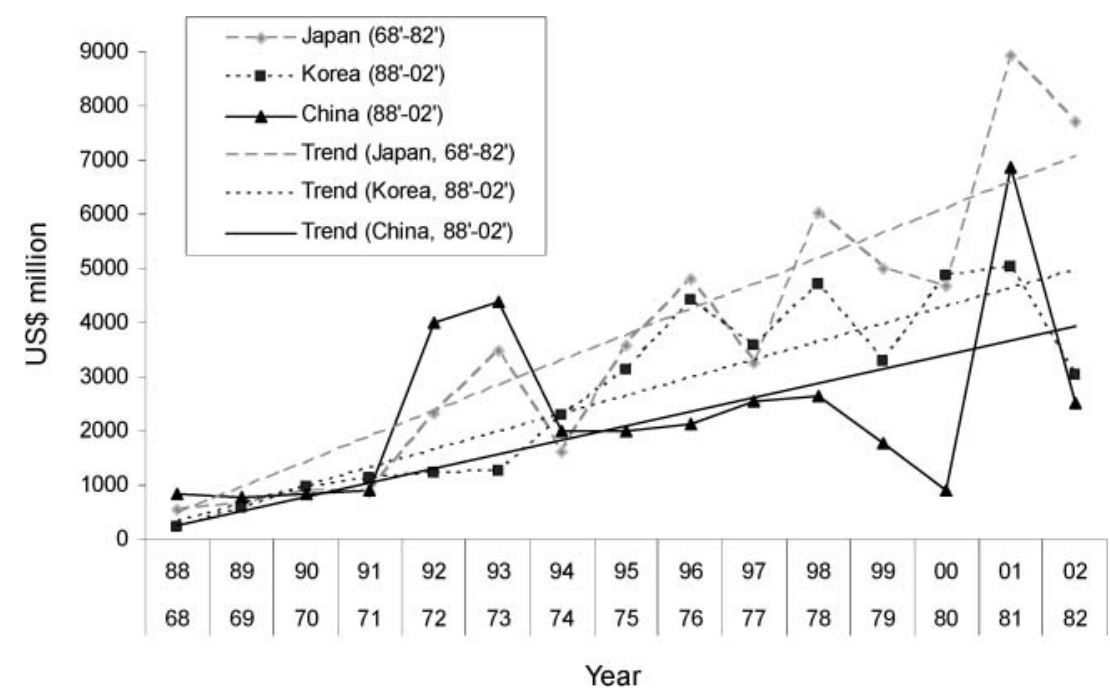

Note:

The outward FDI data of China and Korea are for the period 1988-2002 (the first row below the horizontal axis) and those of Japan for the period 1968-82 (the second row below the horizontal axis).

Sources:

IMF (various years), International Financial Statistics. Overseas Direct Investment Data Base in Export-Import Bank of Korea (http://www.koreaexim.go.kr). Japan Statistics Bureau (various years), Japan Statistical Yearbook.

range of objectives including market seeking, technology seeking, risk diversification and other objectives common to MNCs worldwide.

Recently, Chinese enterprises have adopted transnational M\&A as a major mechanism of overseas expansion and employed international listing as an important channel to raise capital and finance overseas expansion. These dramatic developments have taken place in an economic system which has hitherto been characterized by centralized political control, dominance of state ownership in big businesses, and bureaucratic co-ordination and interference. This sharp contrast makes it inescapable that evolution in government policies would become the most significant explanatory factor for the internationalization of Chinese corporations in general and for the shifts in overseas investment strategies in particular.

In the early years of reform, the approach taken by the Chinese government towards outward FDI was characterized as eclectic, ad hoc or even half-hearted. ${ }^{16}$ Three factors explain this approach: the pragmatic and experimental nature of the early reform; policy

16. Zhang Yongjin, China's Emerging Global Business: Political Economy and Institutional Investigations (Basingstoke and New York: Palgrave Macmillan, 2003), p. 54. 
Figure 2: Gross Fixed Capital Formations in China and South Korea, 1988-2002

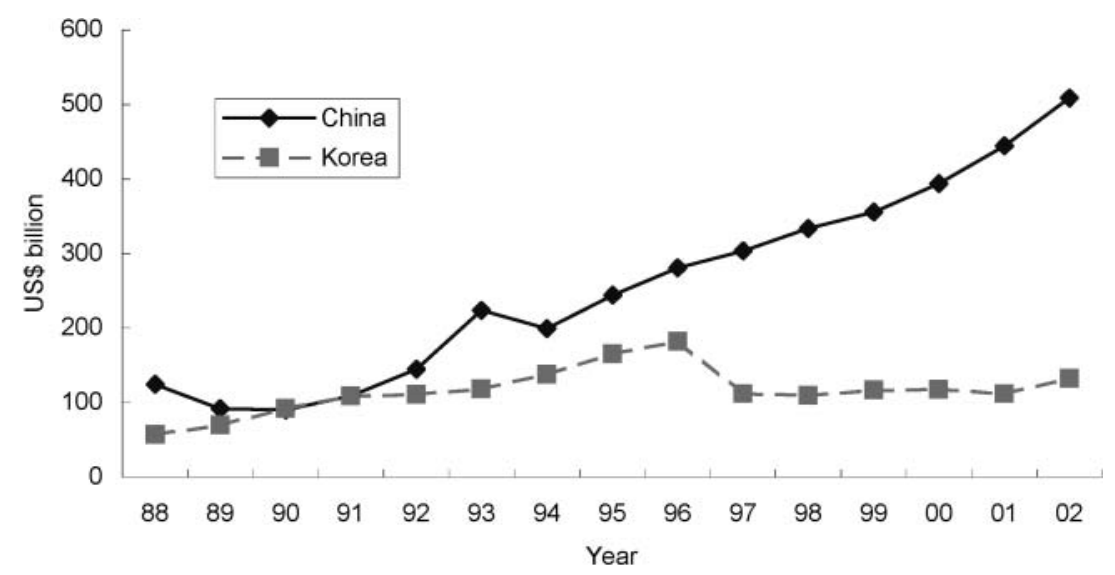

Note:

All conversions are based on the average official exchange rate in the year. Source:

IMF (various years), International Financial Statistics.

Figure 3: The Ratios of Outward FDI to Domestic Gross Capital Formation in China and South Korea, 1988-2002

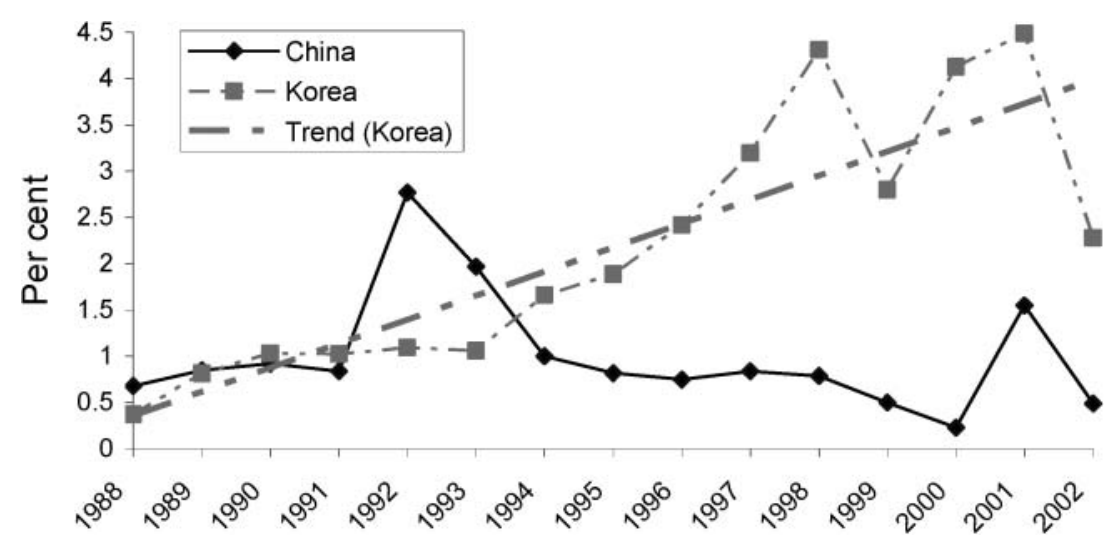

Note and Source:

As Figure 1.

focusing on attracting FDI inflow; and ideological opposition. From 1979 to 1998, a set of policies evolved to either foster and encourage or restrict and regulate outward investment. The starting point was the State Council document issued in August 1979, in which the setting up of overseas operations by Chinese enterprises was 
pronounced as one of 13 official policies for opening the economy. The second important signpost was the release of the "Provisional regulations governing the control and the approval procedure for opening non-trade enterprises overseas" in July 1985 by the Ministry of Foreign Economic Relations and Trade (MOFERT). This document laid down the basic requirements for an overseas investment project to be approved. It affirmed that the government encouraged enterprises to engage in overseas ventures. It also clearly specified requirements that the investment project must meet, and ceilings of approval by the central government and provincial governments. Policies elaborated in this document with regard to procedures and requirements are still applicable today, although the ceilings of approval were raised in 1992, 2002 and $2004 .{ }^{17}$

While these general policies have played an important role in guiding small and medium-sized investment overseas, big players have always depended on cultivating policies which are either firm-specific or case-specific. For example, in November 1978 the Central Committee of the CCP and the State Council jointly approved the establishment of the China State Construction Engineering Co. Ltd which specialized in overseas engineering and construction works and labour services. In 1979, three other such companies were sanctioned by the State Council. These were the China Civil Engineering and Construction Corporation, the China Road and Bridge Engineering Co. Ltd and the China Complete Set Equipment Import and Export Co. Ltd. These four companies were pioneers in the introduction of China to international markets for construction, engineering and labour services. They are now among the largest 225 engineering and construction firms in the world. ${ }^{18}$ In 1987, the State Council approved the application by Sinochem, the largest import and export corporation in China and one with strong lobbying power, to experiment with large-scale international operations.

A more legendary case of such particularistic policies was the establishment of China International Trust and Investment Corporation (CITIC). This initiative was largely a result of a meeting on 17 January 1979 between Deng Xiaoping and the five so-called “red capitalists" (hongse zibenjia 红色资本家) including Rong Yiren (荣毅仁), the founding chairman and general manager of CITIC. CITIC was ranked as a ministerial-level corporation engaged in investment activities both at home and abroad. It enjoyed special permission from the top leaders for certain activities that were not permitted to other enterprises. CITIC's large overseas investment

17. For example, "Regulations for approval and control of non-trade related overseas investment by Chinese enterprises" promulgated by MOFTEC in March 1992 raised the ceiling of approval for MOFTEC and the State Planning Commission from US\$10 million to US\$30 million. In October 2004, a spate of policies was announced to outline basic policies concerning giving credit support to key overseas investment encouraged by the government.

18. Zhang Yongjin, China's Emerging Global Business, p. 88. 
projects for most of the 1980s do not seem to have gone through the screening and approval procedures of the MOFERT, and were certainly not registered in MOFERT's statistics. ${ }^{19}$

In line with the pace of policy evolution, the landscape of overseas investment activities in the early years of the reform (1979-84) was dominated by state-owned foreign trade corporations (either under MOFERT or under the department of foreign economic relation and trade in provincial governments) and by foreign business oriented companies newly created via particularistic policies. ${ }^{20}$ Furthermore, their overseas investment activities were strongly linked to government's political considerations rather than to commercial objectives. The key decisions on overseas investments, including choices of location and sector, were mainly determined by the consideration of enhancing China's political and economic influence and expanding its international trade relationships rather than that of maximizing market profit. ${ }^{21}$ A typical case was China's heavy investment in Hong Kong's public utility and infrastructure sector, which reflected China's desire to strengthen political and economic influence in Hong Kong. ${ }^{22}$ By early 1985, the MOFERT statistics showed that, in total, there were still only 113 non-trade Chinese enterprises overseas with an accumulated investment of about US\$150 million. ${ }^{23}$

The significant (although gradual) decentralization of Chinese economic system since the mid-1980s has brought substantial liberalization in the field of outward FDI. Following the principles announced in the 1985 provisional regulations, all enterprises, if they have sufficient capital, technical and operating know-how, and suitable foreign partners, can apply for permission to establish subsidiaries in foreign countries. ${ }^{24}$ Local governments took advantage of this to push and help local foreign trade corporations and foreign business oriented companies to establish overseas operations. The objectives of these investments were the capital and technology as well as trade expansion gains. As a consequence, in every year since 1987, over 100 new non-trade enterprises have been set up overseas.

Deng's southern tour and the 14th Party Congress in 1992 gave new momentum to overseas investment activities. Generally speaking, the Congress officially brought to an end the political and ideological

19. For an excellent case study of CITIC, see Zhang Yongjin, China's Emerging Global Business, ch. 5, pp. 125-158.

20. Tseng Choosin, "Foreign direct investment"; Cai, "Outward foreign direct investment," pp. 856-880.

21. Wu and Chen, "An assessment," pp. 1235-54; Wang, "The motivations," pp. 187-206.

22. Chan Hing Lin, "Chinese investment," pp. 941-954; Zhang Hai-Yan and Danny van den Bulcke, "China: rapid changes in the investment development path," in John. H. Dunning and Rajneesh Narula (eds.), Foreign Direct Investment and Governments: Catalysts for Economic Restructuring (London: Routledge, 1996).

23. Wu and Chen, "An assessment," pp. 1235-54.

24. Rosalina Tan, "Foreign direct investment flows to and from China," in Ellen H. Palanca (ed.), China's Economic Growth and the ASEAN (Manila: Philippine APEC Study Center Network and the Philippine Institute for Development Studies, 2001). 
controversies with regard to the direction of China's reform. In the case of overseas investment, it explicitly affirmed an official policy of encouraging Chinese firms to invest overseas as part of China's overall strategy of joining global competition. Overseas operations by Chinese companies since this time have been firmly incorporated into the economic development strategy. China's accession to the WTO in November 2001 brought further momentum. In the Tenth Five-Year Plan (announced in 2001), the strategy of enterprises "going out" to invest beyond Chinese borders was described as one of four key thrusts to enable China to "adjust itself to the trend of economic globalization.,"25

Thanks to the two favourable initiatives mentioned above, approval ceilings were raised significantly, many restrictions were relaxed and, more importantly, government officials in charge of screening and approval changed their attitude and became more friendly to the commercial viewpoint. As a result, not only was there a significant increase in overseas investment projects, but the average scale of newly established overseas enterprises grew, from US $\$ 1.5$ million per firm in 1985-89 to US\$2.7 million per firm in 2000-2002. ${ }^{26}$ The increasing diversity of investment actors has brought a significant shift in investment and business strategies. Although the central government officials in charge of screening and approval may still put political considerations first, they have begun to give increasing weight to resource, technology and strategic assets acquisition. And, while local governments and enterprises may initially focus on trade expansion, they have become increasingly interested in reputation and brand building, and in innovative investment mechanisms and financing channels. The analytical focus of following sub-sections is on these dynamic changes.

The dynamics of resource and technology seeking strategies. Resource seeking, in particular natural resource seeking, has been one of the key strategic considerations for China's outward FDI since the very beginning. As shown in Tables 2 and 3, up to 1991 Chinese overseas investment was highly concentrated in North America and Oceania, where Canada and Australia were the two largest recipient countries, attracting US\$360 and US\$313 million respectively. China's investment in these two countries includes China Metallurgical Industrial Corporation's investment in the Channar Mine in Australia, CITIC and China National Non-ferrous Metal Industrial Corporation's investment in the Portland Aluminium Smelter in Australia, CITIC's investment in a sawmill in Canada, and Alberta and the China National Petroleum Corporation's equity

25. Zhu Rongji, "Report on the Tenth Five-Year Plan for the national economic and social development," Renmin ribao, 5 March 2001.

26. MOFTEC, Almanac of China's Foreign Economic Relations and Trade (Beijing: Foreign Relations and Trade Press, various years). 
Table 2: China's Outward FDI in Non-trade Sector by Region (US\$ million and \%)

\begin{tabular}{|c|c|c|c|c|c|c|}
\hline \multirow[b]{2}{*}{ Ranking } & \multicolumn{2}{|c|}{ 1979-1991 } & \multicolumn{2}{|c|}{ 1992-1996 } & \multicolumn{2}{|c|}{ 1997-2002 } \\
\hline & Region & Value $(\%)$ & Region & Value $(\%)$ & Region & Value $(\%)$ \\
\hline 1 & $\begin{array}{c}\text { North } \\
\text { America }\end{array}$ & $656(47.0)$ & Asia & $262(34.6)$ & Asia & 4,773 (66.9) \\
\hline 2 & Oceania & $326(22.4)$ & $\begin{array}{c}\text { Latin } \\
\text { America }\end{array}$ & 149 (19.7) & Africa & $641(9.0)$ \\
\hline 3 & Asia & $203(14.5)$ & Africa & $124(16.4)$ & $\begin{array}{l}\text { North } \\
\text { America }\end{array}$ & $547(7.7)$ \\
\hline 4 & Europe & $82(5.9)$ & Europe & $76(10.0)$ & $\begin{array}{c}\text { Latin } \\
\text { America }\end{array}$ & $498(7.0)$ \\
\hline 5 & $\begin{array}{c}\text { Latin } \\
\text { America }\end{array}$ & $62(4.5)$ & Oceania & $71(9.4)$ & Europe & $394(5.5)$ \\
\hline 6 & Africa & $43(3.7)$ & $\begin{array}{c}\text { North } \\
\text { America }\end{array}$ & 67 (8.9) & Oceania & $153(2.1)$ \\
\hline 7 & $\begin{array}{c}\text { Middle } \\
\text { East }\end{array}$ & $15(1.1)$ & $\begin{array}{l}\text { Middle } \\
\text { East }\end{array}$ & $7(1.0)$ & $\begin{array}{c}\text { Middle } \\
\text { East }\end{array}$ & $126(1.8)$ \\
\hline Total & & $1,396(100)$ & & 757 (100) & & $7,132(100)$ \\
\hline
\end{tabular}

Note:

Data are on an approved basis.

Source:

MOFTEC, various years, Almanac of China's Foreign Economic Relations and Trade.

in an oil extraction project in Canada. ${ }^{27}$ All these Chinese corporations were directly controlled by the central government.

During the 1990s, the natural resource seeking motivation continued its momentum, with increasing emphasis on fuel and general raw materials. This is a natural consequence of China's high economic growth, which led to significant increase in demand for fuel and industrial raw materials. For example, Peru became the largest recipient of China's outward FDI in 1992-96, receiving US\$120 million (Table 3). This can be mainly attributed to the Capital Iron \& Steel's acquisition of Hierro Peru Mining Ltd in November 1992. ${ }^{28}$

Resource-seeking investment, notably in minerals and oil, is usually on a large scale and involves a large portion of corporations' foreign capital. The availability of foreign capital was the tightest constraint on large-scale acquisition until the late 1990s, when large state-owned corporations started to list on the Hong Kong and New York stock exchanges. International listing of resource-based large corporations since has greatly increased the availability of capital in hard currency

27. James Xiaoning Zhan), "Transnationalization and outward investment: the case of Chinese firms," Transnational Corporations, Vol. 4, No. 3 (1995), pp. 67-100; Wang, "The motivations," pp. 187-206.

28. Wu and Chen, "An assessment," pp. 1235-54. 
Table 3: China's Outward FDI in Non-trade Sector by Country (US\$ million)

\begin{tabular}{|c|c|c|c|c|c|c|}
\hline \multirow[b]{2}{*}{ Ranking } & \multicolumn{2}{|c|}{ 1979-1991 } & \multicolumn{2}{|c|}{ 1992-1996 } & \multicolumn{2}{|c|}{ 1997-2002 } \\
\hline & Country & Value (\%) & Country & Value (\%) & Country & Value $(\%)$ \\
\hline 1 & Canada & $360(25.8)$ & Peru & $120(15.8)$ & $\begin{array}{l}\text { Hong } \\
\text { Kong }\end{array}$ & $3,862(54.2)$ \\
\hline 2 & Australia & $313(22.4)$ & $\begin{array}{l}\text { Hong } \\
\text { Kong }\end{array}$ & 113 (14.9) & USA & $482(6.8)$ \\
\hline 3 & USA & $295(21.2)$ & USA & 57 (7.5) & Brazil & $155(2.2)$ \\
\hline 4 & Hong Kong & $99(7.1)$ & Russia & $47(6.2)$ & Mexico & $151(2.2)$ \\
\hline 5 & Russia & $49(3.5)$ & $\begin{array}{c}\text { New } \\
\text { Zealand }\end{array}$ & $41(5.4)$ & Thailand & $148(2.1)$ \\
\hline 6 & Thailand & $38(2.7)$ & $\begin{array}{l}\text { South } \\
\text { Africa }\end{array}$ & $38(5.0)$ & Macao & $139(2.0)$ \\
\hline 7 & Chile & $21(1.5)$ & Macao & $29(3.8)$ & Zambia & $124(1.7)$ \\
\hline 8 & Macao & $16(1.1)$ & Mali & $28(3.7)$ & Russia & $111(1.6)$ \\
\hline 9 & Brazil & $11(0.8)$ & Thailand & $28(3.7)$ & Cambodia & $106(1.5)$ \\
\hline 10 & Malaysia & $10(0.7)$ & Cambodia & $19(2.5)$ & Australia & 105 (1.5) \\
\hline Total & & 1,213 (86.9) & & 519 (68.6) & & $5,384(75.5)$ \\
\hline
\end{tabular}

Note:

Data are on an approved basis.

Source:

MOFTEC, various years, Almanac of China's Foreign Economic Relations and Trade.

to enable them to conduct large-scale acquisitions. As a consequence, the China National Offshore Oil Corporation recently became the largest foreign oil producer in Indonesia after its take-over (for US\$585 million) of Repsol Indonesia in 2002. Other examples include SinoPec's acquisition of oilfields in Algeria for US\$394 million in 2002, PetroChina's acquisition of six oilfields from US interests-controlled Devon Energy in Indonesia for US\$260 million in 2002 and of 50 per cent interest in Amerada Hess Indonesia Holdings for US\$164 million in 2003. Since early 2003, Baosteel, China's biggest steel-maker, has been negotiating the largest overseas manufacturing investment ever by a Chinese company to take a controlling stake, worth US $\$ 1.5$ billion, in a US\$8 billion steel plant in Brazil. ${ }^{29}$ Since mid-2004, the China Minmetals Group has been negotiating for a 100 per cent acquisition of the Canadian nickel and copper mining giant Noranda. China Minmetals was reported to be ready to spend C\$7.5 billion for this acquisition. $^{30}$

Parallel to resource-seeking investment, Chinese enterprises have been urged to obtain access to advanced foreign technologies and

29. The Economist, 6 September 2003, p. 57.

30. http://www.noranda.com. 
managerial know-how so that in the near future they can establish themselves in international markets. For this strategic purpose, the United States has been the most attractive country for China's technology-seeking investment. In 1979-91, the United States was the third largest recipient of China's overseas investment next to Canada and Australia, attracting 21.3 per cent of the total. In 1997-2002, it became the second largest recipient of China's overseas investment (next to Hong Kong) attracting US\$482 million of direct investment from China (Table 3).

There are many cases of success in the acquisition of proprietary technology. One important recent example is the Shanghai Automotive Industry Corporation's $£ 67$ million purchase of the technical rights to manufacture Rover's 25 and 75 models, and the Powertrain business. Another is the Lenovo Group's acquisition of the global PC businesses of IBM for US\$1.25 billion in December 2004.

An earlier example is Shougang's purchase of a 70 per cent equity share of Mesta Engineering Co. Ltd of Pittsburgh in the United States in 1988. The purpose of this acquisition was for Shougang to combine Mesta's design capability and technology with its own machinemanufacturing capability to make large continuous casting and steel rolling equipment. The combination of Mesta Engineering's technological know-how and international reputation with Shougang's machine manufacturing capability proved to be a great technical success and led to Shougang winning important contracts in the early 1990s in India, Indonesia, Macao, Malaysia, the Philippines, and even the United States and Switzerland. Based on such alliances, Shougang quickly turned from being purely a technology importer to being a technology exporter. ${ }^{31}$

The dynamics of market and diversification seeking strategies. An increasing number of Chinese companies, particularly large ones, have engaged in overseas investments for market-seeking and risk diversification. Their expansion abroad has been encouraged by the government, which is keen to see the development of Chinese conglomerate multinationals modelled on the example of the Japanese and Korean trading houses. ${ }^{32}$

One of the best illustrative cases featuring this type of investment is China National Chemicals Import \& Export Corporation (Sinochem). ${ }^{33}$ Sinochem, one of China's largest state-owned foreign trade companies, used to hold a monopoly on the country's import and export of petroleum, chemical fertilizers and raw materials for plastic film. The foreign trade reform of the 1980s led to a gradual

31. Zhang Yongjin, China's Emerging Global Business, pp. 201-202.

32. Peter Nolan and Godfrey Yeung, "Big business with Chinese characteristics: two paths to growth of the firm in China under reform," Cambridge Journal of Economics, Vol. 25, No. 3 (2001), pp. 443-465.

33. Zhang Yongin, China's Emerging Global Business, ch. 6, pp. 157-187. 
erosion of such specialized monopolies. As a result, Sinochem began to lose its core business and had no alternative but to look for new possibilities. Based on a careful assessment of its comparative advantage, Sinochem initiated a threefold transformation in 1987: that is, from a single import-export business to an international trader, from commodity trader to a diversified and multifunctional operation, and from a Chinese foreign trade company to a transnational corporation. These innovative developments were supported and formally approved by the State Council in late 1987. Sinochem was awarded the status of the first pilot corporation in China to diversify its business with the objective of becoming a top multinational.

In the 1990s, Sinochem successfully transformed itself into a diversified multinational corporation, with business activities in petroleum, fertilizer, chemicals, investment, financing, tourism and consultancy across the globe. By 2000, it had set up more than 100 foreign subsidiaries and joint ventures worldwide, with total foreign assets of $\$ 2.8$ billion. Among its largest offshore ventures are Sinochem International Oil (London) Co. Ltd, US Agri-Chemicals Co. Ltd and Sinochem International Oil (Hong Kong) Co. Ltd, each having a turnover of over US\$1 billion. In 2000, Sinochem's combined turnover overseas reached over US $\$ 10$ billion, more than 55 per cent of the total. ${ }^{34}$ As a well-diversified multinational in industry and services, Sinochem has been listed among Global 500 largest corporations by Fortune since 1995. It was ranked eighth by foreign assets among the top 50 multinationals from developing countries in $1998 .^{35}$

Since the mid-1990s, over-supply has become the most challenging issue in industries such as textiles and clothing, bicycles, footwear, and electrical appliances. Many companies decide to "go out" so as to sell their products in foreign markets. However, they are often faced with a variety of trade barriers. In certain product categories, quantitative restrictions are more severe for China than for other countries. This continues to be the case even after China's accession into the WTO. ${ }^{36}$ With the anticipation that protectionist barriers will continue even under the WTO umbrella, increasing numbers of Chinese companies have opted to establish foreign subsidiaries to ensure access to these markets. Textile and clothing factories established by Chinese firms in some African and South Asian countries, as well as assembly plants of bicycles and household appliances in the EU, the US and Latin America, are essentially designed to circumvent trade barriers and to protect and promote exports. The most famous case is that of the Haier Group as mentioned above. Haier established its manufacturing

34. Sinochem Annual Report 2000.

35. UNCTAD, World Investment Report 1999, p. 48.

36. Liu Huan and Sun Laixiang, "Beyond phase-out of quota in textile and clothing trading: WTO-plus rules and the case of US safeguards against Chinese exports in 2003," Asia-Pacific Development Journal, Vol. 11, No. 1 (2004), pp. 49-71. 
facilities and assembly operations in the United States for the purpose of avoiding American quota restrictions and potential anti-dumping suits. In this way Haier has also been able to protect its exports of parts to the US. ${ }^{37}$

Many small and medium-sized Chinese companies have opted to cultivate their comparative advantage in South-East Asia, Africa and Latin America. Investment in these developing areas is largely characterized by small-scale projects, labour-intensive production, and the production of undifferentiated and low-value-added goods. For the production of goods such as textile and clothing, footwear, bicycles, simple electrical appliances, and electronics, Chinese companies do often possess relatively advanced and accessible technologies, managerial skills and better access to international markets, which provide a competitive edge and can be exploited in countries with similar or lower levels of economic development. Thanks to this edge, the Chinese equity contribution to ventures in these countries is often in the form of equipment and machinery, leading to a significant increase of capital goods exports from China. Furthermore, to facilitate the production in host countries, many Chinese companies also export raw materials to their overseas affiliates. ${ }^{38}$

The dynamics of strategic asset seeking. Strategic asset-seeking FDI has been regarded by Dunning as "the most significant change in the motives for FDI over the last two decades."39 Dunning's observation holds for the Chinese case. Many Chinese multinationals invest in the well-developed and highly competitive markets of the US and EU as part of their global production and marketing strategies. One key strategic asset that Chinese companies are actively pursuing is to establish a globally recognized brand name. ${ }^{40} \mathrm{~A}$ case in point is TCL Corporation. $^{41}$

TCL is currently China's second largest colour television and mobile phone maker. It grew out of a small joint-venture company specializing in fixed-line telephone equipment in the early 1980s. In 2003, TCL had business revenue of over US $\$ 3.4$ billion and it sold 11.65 million colour television sets and 9.82 million mobile phones. It started to make significant efforts to promote its brand internationally in 2000 , driven by both the tough competition in domestic market and the ambition of the company for an international presence. The company's efforts mainly consist of seeking joint ventures with global leading producers and cross-border acquisition. In September 2002,

37. Deng and Jian, Made in Galanz; Deng Ping, "Outward investment by Chinese MNCs: motivations and implications," Business Horizons, Vol. 47, No. 3 (2004), pp. 8-16; Sull, Made in China.

38. Deng Ping, "Outward investment," pp. 8-16.

39. John H. Dunning, "Location and the multinational enterprise: a neglected factor?" Journal of International Business Studies, Vol. 29, No. 1 (1998), pp. 45-66.

40. Gilmore and Dumont, Brand Warriors; Sull, Made in China.

41. http://www.tcl.co.cn. 
TCL acquired the German-based Schneider Corporation. This gives TCL a platform in Europe under the brand name of the acquired company, but the impact is limited given the relatively small market share of Schneider. More significant results of this policy started to surface in 2004. In January 2004 TCL signed a contract with Thomson, the French-based and internationally well-known electronics manufacturer, to merge their television and DVD operations under the jointly established TCL-Thomson Electronics Co. Ltd. In August 2004 TCL signed a memorandum of understanding with France-based Alcatel, a world-renowned brand in the telecommunication industry, and the new joint venture, TCL-Alcatel, officially started operation in October 2004.

In the TCL-Thomson joint venture, TCL holds 67 per cent of equity share. The combined production capacity of colour television reached 18.5 million sets in 2003, making it the largest colour television maker in the world. ${ }^{42}$ The joint venture also provides TCL with a number of additional strategic advantages. First, it enables it to pursue a multi-brand strategy in the global market. Thomson licensed its Thomson brand, which has had a market share of 8 per cent in Europe in recent years, and its RCA brand, which has a "doubledigital market share" in the United States, to the new joint-venture. ${ }^{43}$ Secondly, the joint venture brings TCL well-established overseas production bases and distribution channels. For example, Thomson's plant in Juarez, Mexico will be used by TCL-Thomson Electronics to assemble colour televisions for the North American market. Such production bases can help TCL to circumvent non-tariff barriers. ${ }^{44}$ Thirdly, the venture grants TCL opportunities to accelerate its expansion in high-end products, such as high-definition rear projection television, plasma display panels and LDC TV. From Thomson's perspective, a joint venture with the top player in the Chinese market brings in the best access to China's low-cost manufacturing facilities and to the retail markets of China and South-East Asia.

In the TCL-Alcatel joint venture, TCL invests in cash and takes a controlling position of 55 per cent. Alcatel contributes the access to its global GSM/GPRS mobile phone business and Alcatel mPD, which consists of mobile phone R\&D, distribution and sales businesses, equivalent to an equity position of 44 per cent. Through this deal, TCL became the first domestic mobile phone company to expand to overseas markets on a large scale. Alcatel is a world-renowned brand in telecom infrastructure. It has strong relationships with a number of leading wireless telecommunication operators around the world, including Orange and Vodafone in Western and Central Europe, Telefonica in Spain and Latin America, and TIM in Italy. Alcatel

42. Business CustomWire, 29 July 2004.

43. TWICE, 10 November 2003.

44. In December 2003, the US Commerce Department announced provincial antidumping duties against four Chinese colour television makers. TCL's dumping degree was $22.36 \%$ ("TCL Corporation announcement," No. 2004-10). 
mPD has developed strong relationships with a number of mobile phone distributors in various markets, including emerging markets such as China, Malaysia, Thailand, the Middle East and Russia. It also holds a portfolio of GSM mobile phone patents and has had strong R\&D capability in mobile phone technology, all of which have been either transferred or licensed to the TCL-Alcatel Joint Venture. The joint venture provides TCL with the desired assess to the established global network of Alcatel, in addition to technology transfer. For Alcatel, it provides a beneficial way to withdraw gradually from its handset-making business so that it can focus on telecommunication infrastructure business. ${ }^{45}$

\section{Emerging Investment Mechanisms and Financing Channels}

Since the mid-1990s, increasing numbers of Chinese companies have taken to listing on stock exchanges in developed countries as an important way to raise equity capital directly in hard currency and to establish international image and reputation. Between the 1993 listing of Qingdao Beer on the Hong Kong stock exchange and the listing of China Netcom on the New York and Hong Kong stock exchanges in November 2004, 105 Chinese companies listed on stock exchanges in developed countries. In addition, there have been 84 "red chip" companies listed in Hong Kong. These are companies registered in Hong Kong but controlled by mainland interests. The total capital raised was over US\$100 billion. The top three companies in terms of fund-raising are China Mobile (red-chip share) with about US\$14 billion, China Unicom (red-chip share) with US\$5.6 billion and SinoPec (H share) with US\$3.4 billion. $^{46}$

Table 4 shows the top ten Chinese industrial companies listed on Hong Kong (H-share listing) in terms of market capitalization. They have all been leading players in China's overseas investment, and five of the ten are mainly natural resource-based and state-controlled enterprises. By listing on developed capital markets, these companies have not only raised capital in hard currency to finance their international M\&A, but also increasingly adapted to international standards in the areas of corporate governance, accounting and auditing, strategic management, and business conduct.

Largely thanks to the capital raised by the primary offering, ${ }^{47}$ transnational M\&A has gradually become the main form of China's

45. RCR Wireless News, 3 May 2004.

46. Paul Chow, "2004 and beyond - HKEx's perspective," HKEx Chief Executive's presentation at Economic Summit 2004, 16 December 2003; Lawrence Fok, "Views on the financial sector - opportunities in China via Hong Kong," presented at Hong Kong Trade Development Council Conference "Hong Kong: your expressway to China," 17 September 2003; Hong Kong Exchanges and Clearing Ltd website (http:// www.hkex.com.hk).

47. One special feature of SOE privatization in China is that share-issuing firms typically go through primary offerings instead of secondary offerings, which is the norm in almost all other countries. Under secondary offerings the government sells existing equities and receives all the sales proceeds and the only effect on the privatized firms comes 
Table 4: The Top 10 Chinese Companies Listed on Hong Kong Stock Exchange (H-share listing, by market capitalization, and up to 10 December 2004)

\begin{tabular}{|c|c|c|c|c|}
\hline Rank & Company & Principal activities & $\begin{array}{l}\text { Listing } \\
\text { date }\end{array}$ & $\begin{array}{l}\text { Capitalization } \\
\text { (HK\$ million) }\end{array}$ \\
\hline 1 & PetroChina Co. Ltd. & $\begin{array}{l}\text { Exploration and } \\
\text { production of crude } \\
\text { oil and natural gas }\end{array}$ & $\begin{array}{l}7 \text { Apr. } \\
2000\end{array}$ & 72,088 \\
\hline 2 & SinoPec Co. Ltd. & $\begin{array}{l}\text { Exploration and } \\
\text { production of crude } \\
\text { oil and natural gas }\end{array}$ & $\begin{array}{l}19 \text { Oct. } \\
2000\end{array}$ & 51,600 \\
\hline 3 & $\begin{array}{c}\text { China Life Insurance } \\
\text { Co. Ltd. }\end{array}$ & Finance & $\begin{array}{l}18 \text { Dec. } \\
2003\end{array}$ & 41,671 \\
\hline 4 & $\begin{array}{c}\text { China Telecom } \\
\text { Co. Ltd. }\end{array}$ & $\begin{array}{c}\text { Fixed line } \\
\text { telecommunications }\end{array}$ & $\begin{array}{l}15 \text { Nov. } \\
2002\end{array}$ & 38,163 \\
\hline 5 & $\begin{array}{l}\text { Ping An Insurance } \\
\text { (Group) Co. of } \\
\text { China Ltd. }\end{array}$ & Finance & $\begin{array}{l}24 \text { Jun. } \\
2004\end{array}$ & 33,134 \\
\hline 6 & $\begin{array}{l}\text { Huaneng Power } \\
\text { International, Inc. }\end{array}$ & $\begin{array}{l}\text { Construction and } \\
\text { operation of coal- } \\
\text { fuelled power plants }\end{array}$ & $\begin{array}{c}21 \mathrm{Jan} . \\
1998\end{array}$ & 18,179 \\
\hline 7 & $\begin{array}{c}\text { Aluminum Corporation } \\
\text { of China Ltd. }\end{array}$ & $\begin{array}{l}\text { Production and } \\
\text { distribution of } \\
\text { aluminium }\end{array}$ & $\begin{array}{l}12 \text { Dec. } \\
2001\end{array}$ & 15,097 \\
\hline 8 & $\begin{array}{c}\text { Yanzhou Coal Mining } \\
\text { Co. Ltd. }\end{array}$ & $\begin{array}{l}\text { Underground } \\
\text { coal mining }\end{array}$ & 1 Apr. 1998 & 13,158 \\
\hline 9 & $\begin{array}{l}\text { PICC Property and } \\
\text { Casualty Co. Ltd. }\end{array}$ & Finance & 6 Nov. 2003 & 9,504 \\
\hline 10 & $\begin{array}{c}\text { China Shipping } \\
\text { Development Co. Ltd. }\end{array}$ & $\begin{array}{l}\text { The shipment of oil } \\
\text { and cargoes }\end{array}$ & $\begin{array}{l}11 \text { Nov. } \\
1994\end{array}$ & 8,878 \\
\hline
\end{tabular}

Source:

Hong Kong Exchanges and Clearing Limited (http://www.hkex.com.hk).

direct investment abroad. Table 5 reports the rise of M\&A in Chinese overseas expansion. It shows that within 12 years, the value of cross-border M\&A purchased by Chinese companies increased from US\$60 million in 1990 to 1.65 billion in 2003, a 27-fold increase. In sharp contrast to the remarkable decrease of M\&A acquisitions by Japan, South Korea and Taiwan since the mid-1990s, since 2002

footnote continued

from ownership change. In contrast, under the primary offerings, share-issuing is a capital-raising event for the firm. Share-issuing increases a firm's asset and equity accounts by an equal amount, and consequently changes the firm's ownership structure somewhat (Sun Qian and Wilson H.S. Tong, "China share issue privatization: the extent of its success," Journal of Financial Economics, Vol. 70 (2003), pp. 183-222. 
Table 5: Cross-border M\&A by Country of Purchaser in Asia, 19902003 (US\$ million)

\begin{tabular}{lrrrrrr}
\hline & 1990 & 1995 & 2000 & 2001 & 2002 & 2003 \\
\hline China & 60 & 249 & 470 & 452 & 1,047 & 1,647 \\
Japan & 14,048 & 3,943 & 20,858 & 16,131 & 8,661 & 8,442 \\
Hong Kong & 1,198 & 2,299 & 5,768 & 3,012 & 5,062 & 4,168 \\
India & - & 29 & 910 & 2,195 & 270 & 1,362 \\
Indonesia & 49 & 163 & 1,445 & - & 197 & 2 \\
Malaysia & 144 & 1,122 & 761 & 1,375 & 930 & 3,685 \\
Philippines & - & 153 & 75 & 254 & 2 & 1 \\
South Korea & 33 & 1,392 & 1,712 & 175 & 98 & 662 \\
Singapore & 438 & 892 & 8,847 & 16,516 & 2,946 & 5,018 \\
Taiwan & 1,385 & 122 & 1,138 & 161 & 74 & 253 \\
Thailand & 18 & 144 & 5 & 699 & 87 & 176 \\
\hline
\end{tabular}

Note:

The data cover the deals involving the acquisition of an equity stake of more than $10 \%$.

Source:

UNCTAD, World Investment Report 2004, Annex table B.8, pp. 416-19.

China has risen to the fifth ranked economy in the M\&A in Asia, following Japan, Hong Kong, Singapore and Malaysia. ${ }^{48}$ The major explanations for this increased M\&A by Chinese companies include the need for direct access to natural resources, overcoming the low brand value of Chinese products, and obtaining as quickly as possible advanced marketing and distribution networks and R\&D operations.

Table 6 reports the leading M\&A acquired by Chinese companies in 2002-2004. China's four major oil companies account for a large share of cross-border M\&A deals. It is worth noting that all these large deals took place after successful initial public offerings (IPOs) of these oil companies in Hong Kong and New York. The case of PetroChina illustrates the contribution of international listing to large cross-border M\&A. PetroChina is currently the largest producer of crude oil and natural gas in China and was ranked second in Fortune's 2002 list of China's top 100 companies. It was incorporated in November 1999 as a result of a comprehensive restructuring of China National Petroleum Corporation (CNPC) with the purpose of seeking a listing in Hong Kong and New York. This IPO-motivated restructuring was regarded as China's most ambitious reform project before 2001. After five months of preparation, in April 2000, PetroChina completed a global IPO pursuant. The shares issued to the public represented 10 per cent of the total capital of the company. The outstanding 160 billion shares were state-owned and held by 
Table 6: Major Cross-border M\&A by Chinese Companies, 2002-2004 (US\$ million)

\begin{tabular}{|c|c|c|c|c|}
\hline & Acquirer & Target & Industry & Value \\
\hline 2002M1 & $\begin{array}{l}\text { China National } \\
\text { Offshore Oil Corp } \\
\text { (CNOOC) }\end{array}$ & $\begin{array}{l}\text { Spanish Repsol-YPE's } \\
\text { five oil fields (equity } \\
\text { stake), Indonesia }\end{array}$ & Energy & 585 \\
\hline $2002 \mathrm{M} 1$ & $\begin{array}{l}\text { China National } \\
\text { Petroleum Corp. } \\
\text { (CNPC) }\end{array}$ & $\begin{array}{l}30 \% \text { interest in two } \\
\text { oilfields, Azerbaijan }\end{array}$ & Energy & 52 \\
\hline 2002M1 & $\begin{array}{c}\text { China } \\
\text { Petrochemical } \\
\text { Corp. (SinoPec) }\end{array}$ & Oil field assets, Algeria & Energy & 394 \\
\hline 2002M4 & Petro China & $\begin{array}{l}\text { US Devon Energy's six } \\
\text { oil fields in Indonesia }\end{array}$ & Energy & 260 \\
\hline 2002M5 & Haixin Group & $\begin{array}{l}\text { Glenoit Corp.'s sliver knit } \\
\text { pile fabric division, US }\end{array}$ & Fabric & 14 \\
\hline 2002M6 & BaoSteel Group & $\begin{array}{l}46 \% \text { interest in Rio } \\
\text { Tino's mining company, } \\
\text { Australia }\end{array}$ & Steel & 30 \\
\hline $2002 \mathrm{M} 7$ & CNOOC & $\begin{array}{l}\text { BP's refinery assets in } \\
\text { Indonesia }\end{array}$ & Energy & 275 \\
\hline $2002 \mathrm{M} 8$ & CNOOC & $\begin{array}{l}5 \% \text { interest in Northwest } \\
\text { Shelf Venture's oil } \\
\text { fields, Australia }\end{array}$ & Energy & 320 \\
\hline 2002M9 & TCL & $\begin{array}{l}\text { Schneider Electronics, } \\
\text { Germany }\end{array}$ & Electronics & $8.2(€)$ \\
\hline $2002 \mathrm{M} 10$ & $\begin{array}{l}\text { Shanghai } \\
\text { Automotive } \\
\text { Industry } \\
\text { Corporation } \\
\text { (SAIC) }\end{array}$ & $\begin{array}{l}\text { GM-Daewoo Motor } \\
\text { alliance (equity } \\
\text { stake), Korea }\end{array}$ & Automobile & 60 \\
\hline 2002M11 & China Netcom & $\begin{array}{l}\text { Asia Global Crossing } \\
\text { Ltd., Hong Kong }\end{array}$ & Telecoms & 270 \\
\hline $2003 \mathrm{M} 2$ & $\begin{array}{c}\text { BOE } \\
\text { Technology }\end{array}$ & $\begin{array}{l}\text { Hydis (Hynix } \\
\text { Semiconductor's } \\
\text { TFT-LCD division), } \\
\text { Korea }\end{array}$ & TFT-LCD & 380 \\
\hline $2003 \mathrm{M} 4$ & PetroChina & $\begin{array}{l}50 \% \text { stake in } \mathrm{AHIH} \\
\text { (Amerada Hess } \\
\text { Indonesia Holdings) }\end{array}$ & Energy & 164 \\
\hline $2003 \mathrm{M} 7$ & $\begin{array}{c}\text { D’Long } \\
\text { International } \\
\text { Strategic } \\
\text { Investment Co., } \\
\text { Ltd }\end{array}$ & $\begin{array}{l}\text { German Fairchild } \\
\text { Dornier's } 728 \\
\text { development program }\end{array}$ & $\begin{array}{c}\text { Aircraft } \\
\text { manufacturing }\end{array}$ & 10 \\
\hline $2003 \mathrm{M} 7$ & $\begin{array}{l}999 \text { Enterprise } \\
\text { Group }\end{array}$ & $\begin{array}{l}\text { Japanese Kanebo } \\
\text { Ltd.'s herbal } \\
\text { medicine business }\end{array}$ & Pharmacy & 189 \\
\hline
\end{tabular}


Table 6 (Continued)

\begin{tabular}{|c|c|c|c|c|}
\hline & Acquirer & Target & Industry & Value \\
\hline 2003 M10 & $\mathrm{CNOOC}$ & $\begin{array}{l}\text { 12.5\% stake in Gorgon } \\
\text { liquefied natural gas } \\
\text { field, Australia }\end{array}$ & Energy & 275 \\
\hline 2003M12 & $\begin{array}{c}\text { D'Long } \\
\text { International } \\
\text { Strategic } \\
\text { Investment Co., } \\
\text { Ltd }\end{array}$ & $\begin{array}{l}\text { Murray Inc., US } \\
\quad(100 \% \text { equity stake })\end{array}$ & $\begin{array}{c}\text { Machinery } \\
\text { (Environment) }\end{array}$ & 80 \\
\hline 2004M7 & SAIC & $\begin{array}{l}\text { MOU with Ssangyong } \\
\text { Motor, Korea } \\
\text { (48.92\% equity stake) }\end{array}$ & Automobile & 500 \\
\hline 2004M8 & $\begin{array}{c}\text { China Aviation } \\
\text { Oil (Singapore) } \\
\text { Corporation Ltd }\end{array}$ & $\begin{array}{l}\text { Purchase } 20.8 \% \text { stake in } \\
\text { Singapore Petroleum } \\
\text { Company Ltd. }\end{array}$ & Energy & 227 (S\$) \\
\hline $2004 \mathrm{M} 12$ & $\begin{array}{c}\text { Lonovo Group } \\
\text { Ltd }\end{array}$ & $\begin{array}{l}\text { IBM's Personal } \\
\text { Computer } \\
\text { (PC) business }\end{array}$ & $\begin{array}{c}\text { Personal } \\
\text { computer (PC) }\end{array}$ & $\$ 1750$ \\
\hline
\end{tabular}

Source:

Global M\&A Research Centre in Institute of World Economics and Politics, Chinese Academy of Social Sciences (http://www.online-ma.com.cn), PriceWaterhouseCoopers' (PWC) Asia-Pacific M\&A Bulletin (http://www.pwchk.com), and websites of these companies.

CNPC. Thanks to the capital-raising nature of the primary offering, the net proceeds to the company were about US\$2.4 billion.

The success of this IPO not only produced significant net proceeds in hard currency, but also established the image of PetroChina in the international capital market and strengthened its ability to conduct international acquisitions. Soon after the IPO, PetroChina started to look for overseas investment opportunities. In April 2002, the company achieved a breakthrough after researching and assessing more than 20 opportunities. It acquired all the share capital in Devon Energy Indonesia Ltd, a company in Indonesia controlled by American interests and engaged in exploration and production of crude oil and natural gas. This business showed a production capacity of 17,100 barrels (oil equivalence) per day in 2002 and 22,200 barrels per day in 2003. In 2002, the business contributed turnover of US\$76 million and operating profit of US\$16 million to PetroChina. After this initial success, in April 2003 the company completed the acquisition of a 50 per cent equity position in Amerada Hess Indonesia Holdings Ltd for US\$82 million. It is now studying and preparing to take part in a tender for ten new oil blocks in East Java offered by Indonesian government. ${ }^{49}$ 


\section{Conclusions and Implications}

This article has assessed the progress of China's outward FDI and compared this development with the experience of Korea and Japan. The assessment indicates that, at the aggregate level, China and Korea had similar growth trends during 1988-2002, and these trends resembled those observed in Japan during 1968-82. However, further examination of the dynamics of the ratio of outward FDI to domestic fixed capital formation reveals that Korean direct investment abroad is relatively independent of domestic fixed capital formation, whereas in the case of China, outward FDI is more closely correlated to fluctuations in domestic fixed capital formation. This implies that, contrary to first impressions, Korea is in fact the more mature capital exporter.

In terms of the strategic orientation of China's outward FDI, while natural resource-seeking investment has continued its expansion since the 1970s, an increasing emphasis has been placed on M\&A purchases of fuel resources and general raw materials producers. Further, in addition to the resource-seeking investment, increasing numbers of Chinese enterprises are using cross-border M\&A, joint venture and green-field investment to obtain accesses to advanced foreign technologies, managerial know-how, R\&D establishments, and distributional networks and brand names in developed economies. Chinese enterprises have also increasingly cultivated their technological and managerial leads in South-East Asia, Africa and Latin America. For example, increasing numbers of Chinese companies have established production bases in Africa to supply the local markets with cheap products highly compatible with local demands and purchasing power.

To establish a clear international image and to raise capital in hard currencies, increasing numbers of Chinese companies have listed on developed stock exchanges as an important internationalization strategy. By 30 November 2004, 105 Chinese companies had listed in Hong Kong, New York, London and Singapore, and another 84 "red chip" companies are listed and registered in Hong Kong but are controlled by mainland interests. In total, these companies have raised equity capital of over US\$100 billion.

The huge amount of capital raised via international IPOs has brought new momentum to Chinese multinationals' overseas investments. China has emerged as a leading foreign investor in the world. FDI outflows from China are highly motivated and are expected to continue in the foreseeable future. Despite problems and inconsistencies in government policies, the government is now drafting new regulations to provide a better framework for approval and monitoring of outward FDI. With its accession to the WTO and intensified domestic competition, China will continue to liberalize outward FDI policies and actively encourage enterprises to invest overseas in order to sharpen their competitive edge and make the 
economy a key player in the global scene. With its sustained high economic growth, China has not only substantial foreign capital inflows but also a big current account surplus, huge foreign reserves and a high level of domestic savings. All these factors together will support strong expansion of FDI from Chinese multinationals in the near future.

At the firm level, many Chinese companies have accumulated indigenous assets over two decades of growth as a result of huge inward FDI and superior technology transfer. Internationalization has now become imperative for most large Chinese corporations. In addition, the worldwide liberalization of FDI regimes, coupled with trade barriers on Chinese exports, will further stimulate Chinese companies to invest overseas to maintain existing markets and to seek new ones. While continuing to acquire access to raw materials and markets, Chinese companies will place more emphasis on acquisitions of strategic assets and proprietary knowledge in developed economies. All these trends are supported by the government's encouragement to Chinese multinationals to join the ranks of the Fortune Global 500.

To conclude, we suggest two strategic implications of these trends for Western multinationals. First, the success of many Chinese companies in competitive industries such as electronics and household appliances is built on competitive advantages that can still be regarded as classic competitive paradigms: more flexible, faster response, more customer focused and less product focused, highly valuing the accumulation of minor innovation, and sensitive to both products and R\&D niche markets. The case of TCL illustrates the merits of such competitive paradigms. The experiences of these Chinese companies are similar to those of the Koreans about one decade earlier, and to those of the Japanese two or more decades earlier. Moreover, as argued by Jonathan Woetzel, a Shanghai director at Mckinsey \& Company Inc., Chinese companies are already improving on these historical paths in that they are "more entrepreneurial, flexible and much more focused on profit than the Japanese. They change management and won't be patient. They use capital more efficiently." 50 In this sense, the story of the experience of Western companies in competition with Korean and Japanese companies one or two decades ago may be helpful.

Secondly, Chinese experience raises again the question: how can a company from a developing country with limited resources and weak technological background come to our market and take away our market share? In particular, the method used by Chinese companies to overcome their technological disadvantages deserves more attention. It demonstrates that it is possible for companies from developing countries to overcome technological disadvantages by setting up $\mathrm{R} \& \mathrm{D}$ centres in developed countries, and by acquisition, joint venture

50. Economist, p. 57. 
and development of strategic alliances with Western companies for technological development. The combination of $\mathrm{R} \& \mathrm{D}$ acquisition abroad and cost advantage at home can bring significant competitive advantages to Chinese companies. Facing new competitors from China, the best strategy for the Western peers to maintain their lead would be to conduct R\&D more intensively rather than to simply defend their technologies. It is also worth considering the trade-off of advance and retreat so that the company can focus on its sharp competitive advantage and retreat from those with declining competitive advantage, as discussed in the case of Alcatel's alliance strategy with TCL. 



\section{Additional copies}

Further copies of this IIASA Reprint are available online at www.iiasa.ac.at/Publications

Hard copies are also available for a small handling charge. Orders must include the publication number and should be sent to the Publications Department, International Institute for Applied Systems Analysis, A-2361 Laxenburg, Austria.

Telephone: +432236807

Telefax: +43223671313

E-mail: publications@iiasa.ac.at 
International Institute for Applied Systems Analysis

Schlossplatz 1, A-2361 Laxenburg, Austria

Tel: +43 2236807 Fax: +43 223671313

II AS A www.iiasa.ac.at 